Article

\title{
Synthesis Single Crystal X-ray Structure DFT Studies and Hirshfeld Analysis of New Benzylsulfanyl- Triazolyl-Indole Scaffold
}

\author{
Ahmed T. A. Boraei ${ }^{1, *}$, Saied M. Soliman ${ }^{2, *}$, Sammer Yousuf ${ }^{3}$ and Assem Barakat ${ }^{4, *(D)}$ \\ 1 Chemistry Department, Faculty of Science, Suez Canal University, Ismailia 41522, Egypt \\ 2 Department of Chemistry, Faculty of Science, Alexandria University, P.O. Box 426, Ibrahimia, \\ Alexandria 21321, Egypt \\ 3 H.E.J. Research Institute of Chemistry, International Center for Chemical and Biological Sciences, \\ University of Karachi, Karachi 75270, Pakistan; dr.sammer.yousuf@gmail.com \\ 4 Department of Chemistry, College of Science, King Saud University, P. O. Box 2455, \\ Riyadh 11451, Saudi Arabia \\ * Correspondence: ahmed_hassan@science.suez.edu.eg (A.T.A.B.); saeed.soliman@alexu.edu.eg (S.M.S.); \\ ambarakat@ksu.edu.sa (A.B.); Tel.: +966-11467-5901 (A.B.); Fax: +966-11467-5992 (A.B.)
}

Received: 10 July 2020; Accepted: 5 August 2020; Published: 7 August 2020

\begin{abstract}
Benzylsulfanyl-triazolyl-indole scaffold was synthesized through coupling of 4-amino5-(1H-indol-2-yl)-1,2,4-triazol-3(2H)-thione and benzyl bromide in EtOH under basic conditions $\left(\mathrm{K}_{2} \mathrm{CO}_{3}\right)$. The benzylation direction was deduced from the ${ }^{13} \mathrm{C}$ NMR signal found at $35.09 \mathrm{ppm}$, assigned for the methylene carbon of the benzyl group, this value indicates that the benzyl group attacks sulfur, not nitrogen. ${ }^{1} \mathrm{H}$ NMR, ${ }^{13} \mathrm{C}$ NMR, COSY, HMQC, HRMS and X-ray single crystal diffraction analysis were used for structure assignment. The desired compound accomplished in good yield. Hirshfeld analysis revealed the importance of the short N...H (1.994-2.595 Á), S...H (2.282 ̊́) and C...H (2.670 Á) contacts as well as the weak $\pi-\pi$ stacking interactions in the molecular packing of benzylthio-triazolyl-indole scaffold. Its electronic and structural aspects were predicted using density functional theory (DFT) calculations and the reactivity descriptors as well. The Uv-Vis spectral bands were assigned based on the time-dependant density functional theory TD-DFT calculations, while the gauge-including atomic orbitals (GIAO) method was used to predict the ${ }^{1} \mathrm{H}$ and ${ }^{13} \mathrm{C}$ NMR chemical shifts.
\end{abstract}

Keywords: triazolyl-indole; thiol; DFT; Hirshfeld surface analysis

\section{Introduction}

The 1,2,4-triazole scaffold is a remarkable ring in the field of medicinal chemistry and synthon for many molecules with high importance in pharmaceutical field [1-5]. Many drugs on the market are decorated with the triazole motif. Letrozole (anti-cancer agent), Fluconazole (anti-fungal agent), and Maraviroc (Anti-HIV agent) are common drugs bearing the triazole motif. The introduction of thiol and amino groups into positions 3 and 4 of 1,2,4-triazole core structure make this scaffold highly desirable, because it can provide a divergent in the molecular complexity with promising medicinal targets [6,7] such as antifungal, [8] antimicrobial, [9], corrosion inhibitors [10], and also as a chelating agent with metals for fluorescent applications [11].

One of the most privileged structures known in the field of chemistry is the indole scaffold, which has been proven to be active for cancer treatment [12]. The cytotoxicity of the substituted indole compounds has been widely explored towards many of the human cancer lines, for example, the MOLT-3 and HepG-2 cancer cell lines [13], breast cancer cell lines (MCF-7) [14], parental (HCT15 
and MES-SA) promyelocytic leukemic cells [15], and multidrug-resistant (MDR; HCT15/CL02 and MES-SA/DX5) cell lines [16], and other cancer cell lines as well $[17,18]$. The combination of the indole moiety with variety of other privilege core structure, for example, triazoles, [19], thiazoles [20], and sulfonamides [21], leads to the enhancement of the anticancer activity [22].

In 2013, the Westwell, A.D. group synthesized a series of compounds by attaching position 3of the indole ring with 4-amino-3-benzylthio-1,2,4-triazole, which have been exhibited a potential pro-apoptotic Bcl-2-inhibitory anticancer activities [23].

On the other hand, Boraei, A.T.A. and his group focused on linking the substituted 1,2,4-triazoles to position 2- of the indole moiety. The new entities proved to be active towards MCF-7 and HEPG-2 cancer cell with $\mathrm{IC}_{50}=4.53 \mu \mathrm{g} / \mathrm{mL}$ and $3.58 \mu \mathrm{g} / \mathrm{mL}$, respectively, compared with the positive control doxorubicin ( $\mathrm{IC}_{50} 4.0 \mu \mathrm{g} / \mathrm{mL}$ ) which can possibly act as EGFR and Akt inhibitors [24]. The group has been reported a series of compounds having both scaffold indoles and triazole moieties as a representative example, which proved to act as PARP-1 inhibitors [25]. Zhang, $X-R$. and his co-workers, in 2008, reported the X-ray single crystal of 3-benzyl-sulfanyl-5-(4-phenyl-1H-1,2,3-triazol-1-ylmeth-yl)4H-1,2,4-triazol-4-amine [26].

Building on the findings mentioned above, and continuing in our research program [27-31], we have reported the synthesis of a new S-benzylated compound based on the indole and 1,2,4-triazole moieties. The new hit structure was assigned based on the nuclear magnetic resonance and X-ray diffraction analyses. Hirshfeld analysis and density functional theory (DFT) study were also explored.

\section{Materials and Methods}

\subsection{General}

Melting points are uncorrected and measured using a melting-point apparatus (SMP10) in open capillaries. The progress of the reaction was observed by thin layer chromatography (TLC) using ethyl acetate/n-hexane 1:1 as eluent. ${ }^{1} \mathrm{H}$ NMR and ${ }^{13} \mathrm{C}$ NMR and 2D NMR spectra were recorded using a Brucker $300 \mathrm{MHz}$ spectrometer in DMSO- $d_{6}$ using TMS as internal standard. Mass spectra were recorded on JMS-600H JEOL spectrometer. $\lambda$ max was measured using T90 + UV/VIS spectrometer. All software employed in this study, including X-ray diffraction analysis, Hirshfeld surface analysis, and computational methods, are described in the Supplementary Materials. Starting material 1 was synthesized in our laboratory at Suez Canal University (Ismailia, Egypt), benzyl bromide, $\mathrm{K}_{2} \mathrm{CO}_{3}$ and ethanol were purchased from Merck (Munich, Germany).

\subsection{S-Benzylation Method for the Synthesis of 3-(Benzylsulfanyl)-5-(1H-Indol-2-yl)-4H-1,2,4-Triazol-4- Amine 2}

A mixture of 4-amino-5-(1H-indol-2-yl)-1,2,4-triazol-3(2H)-thione $\mathbf{1}(1.0 \mathrm{mmol}, 0.23 \mathrm{~g})$ and $\mathrm{K}_{2} \mathrm{CO}_{3}$ $(1.2 \mathrm{mmol}, 0.17 \mathrm{~g})$ in abs. ethanol $10 \mathrm{~mL}$ was stirred at room temperature for $1 \mathrm{~h}$, then the benzyl bromide $(1.2 \mathrm{mmol}, 0.19 \mathrm{~g})$ was added and stirring was continued overnight, the progress of the reaction was monitored using thin layer chromatography until $\mathbf{1}$ is completely consumed. The solvent was removed under vacuum, cold water was added and the precipitate was collected by filtration, dried and recrystallized from ethanol.

Yield: 87\%, m.p. $270-271{ }^{\circ} \mathrm{C} ;{ }^{1} \mathrm{H}$ NMR (DMSO- $\left.d_{6}, 300 \mathrm{MHz}\right) \delta 4.45(\mathrm{~s}, 2 \mathrm{H}, \mathrm{SCH} 2 \mathrm{Ph}$ ), $6.21(\mathrm{~s}, 2 \mathrm{H}$, $\left.\mathrm{NH}_{2}\right), 7.03\left(\mathrm{dd}, 1 \mathrm{H}, J_{4,5} 7.8, J_{5,6} 7.2 \mathrm{~Hz}, \mathrm{H}-5_{\text {indole }}\right), 7.16\left(\mathrm{dd}, 1 \mathrm{H}, J_{5,6} 7.2, J_{6,7} 7.8 \mathrm{~Hz}, \mathrm{H}-6_{\text {indole }}\right), 7.23-7.35$ $\left(3,4 \mathrm{H}, \mathrm{H}-3_{\text {indole }}+3 \mathrm{H}_{\mathrm{Ph}}\right), 7.45\left(\mathrm{~d}, 3 \mathrm{H}, J 7.8 \mathrm{~Hz}, \mathrm{H}-7_{\text {indole }}+2 \mathrm{H}_{\mathrm{Ph}}\right), 7.60\left(\mathrm{~d}, 1 \mathrm{H}, J_{4,5} 7.8 \mathrm{~Hz}, \mathrm{H}-4_{\text {indole }}\right)$, $11.74\left(\mathrm{~s}, 1 \mathrm{H}, \mathrm{NH}_{\text {indole }}\right) ;{ }^{13} \mathrm{C}$ NMR (DMSO- $\left.d_{6}, 75 \mathrm{MHz}\right) \delta 35.09\left(\mathrm{SCH}_{2} \mathrm{Ph}\right), 102.34\left(\mathrm{C}-3_{\text {indole }}\right), 111.85$ (C-7 indole $), 119.62$ (C-5 $\left.5_{\text {indole }}\right), 120.76$ (C-4 indole $), 122.83$ (C-6 indole $), 123.98$ (C-2 indole $), 127.39\left(\mathrm{CH}_{p-\mathrm{Ph}}\right)$, 127.60 (C-3a $\left.\mathrm{a}_{\text {indole }}\right), 128.44\left(2 \mathrm{CH}_{\mathrm{Ph}}\right), 129.04\left(2 \mathrm{CH}_{\mathrm{Ph}}\right), 136.51$ (C-7a indole $), 137.45\left(\mathrm{C}_{\mathrm{Ph}}\right), 149.31\left(\mathrm{C}_{\text {triazole-indole }}\right)$, 152.85 (C Criazol-S-Bn $_{\text {tro }}$; LREIMS m/z (Int. \%): 65.1 (15.2\%), 89.1 (11.8\%), 90.2 (6.9\%), $91.1(100 \%), 106.2$ (29\%), $142.1(29.6 \%), 143.2(26.3 \%), 321.2\left(28.6 \% \mathrm{M}^{+}\right), 322.2(6.8 \% \mathrm{M}+1)$; HRMS (EI) calcd for $\mathrm{C}_{17} \mathrm{H}_{15} \mathrm{~N}_{5} \mathrm{~S}\left(\mathrm{M}^{+}\right)$: 321.1048. Found: 321.1055 . 


\section{Results and Discussion}

\subsection{Synthesis of the Target Compound and Structural Elucidation}

4-Amino-5-(1H-indol-2-yl)-1,2,4-triazol-3(2H)-thione 1 was synthesized, according to the reported procedures in [32], and reacted with benzyl bromide in the presence of $\mathrm{K}_{2} \mathrm{CO}_{3}$ in EtOH and stirring overnight. Coupling was explored that it proceed at sulfur to give 3-(benzylsulfanyl)-5-(1Hindol-2-yl)-4H-1,2,4-triazol-4-amine 2 (Scheme 1). The compound 2 was obtained in a pure form after recrystallization. The chemical feature of the S-benzylated compound has been assigned based on NMR and X-ray diffraction analysis.

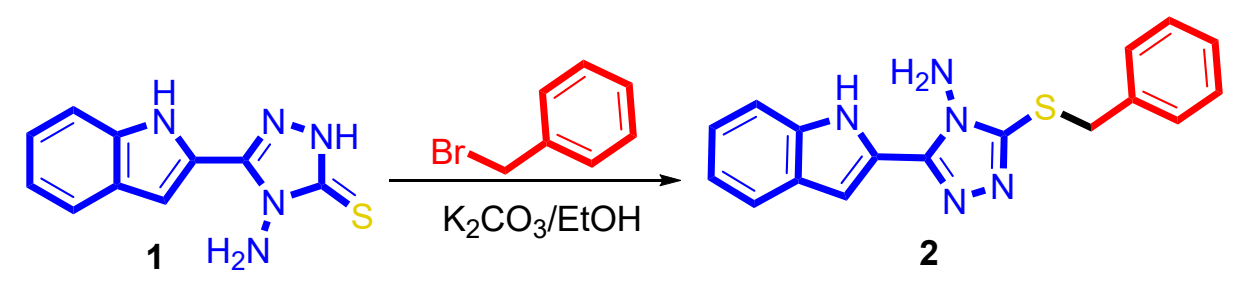

Scheme 1. Synthesis of the 3-(benzylthio)-5-(1H-indol-2-yl)-4H-1,2,4-triazol-4-amine, 2.

The structure of 3-(benzylsulfanyl)-5-(1H-indol-2-yl)-4H-1,2,4-triazol-4-amine was confirmed based upon its NMR and mass spectral data. ${ }^{1} \mathrm{H}$ NMR displayed the methylene protons of the benzyl group at $4.45 \mathrm{ppm}$, the amino group protons appeared at $6.21 \mathrm{ppm}$, the indole and phenyl $\mathrm{CH}$ protons appeared between 7.03 and $7.60 \mathrm{ppm}$, and the indole $\mathrm{NH}$ was found at $11.74 \mathrm{ppm} .{ }^{13} \mathrm{C} \mathrm{NMR}$ demonstrated the methylene carbon of the benzyl group at $35.09 \mathrm{ppm}$, the indole and phenyl $\mathrm{CH}$ carbons appeared as eight signals between 102.35 and $129.05 \mathrm{ppm}$. The quaternary carbons appeared at 123.98, 127.60, 136.51, 137.46, 149.91 and $152.85 \mathrm{ppm}$. Sulfur not nitrogen alkylation was confirmed from the methylene carbon signal of the benzyl group which was found in ${ }^{13} \mathrm{C} N M R$ at $35.09 \mathrm{ppm}$. ${ }^{1} \mathrm{H}-{ }^{1} \mathrm{H}$ correlation spectroscopy (COSY) was used for assigning the correlation between the vicinal protons, and 2D HMQC showed the correlation between the carbons and directly attached hydrogens (all the spectrum are provided in the Supplementary Information, Figures S1-S6)).

\subsection{Structural Features of the Target Compound}

The structure of 2 crystallized in monoclinic crystal system and space group $C 2 / c$ with one molecule per asymmetric unit and $Z=8$. The structure details and refinement parameters are listed in Table 1 . Tables S1 and S2 (Supplementary data) contains the geometric parameters of $\mathbf{2}$, as obtained from the $\mathrm{X}$-ray structure. The structure comprised three planar rings which are the indole (ring A), triazole (ring B) and phenyl (ring C) moieties (Figure 1). The two rings A and B are slightly not coplanar, where the angle between the mean planes through them is only $8.2^{\circ}$. In contrast, the two rings $B$ and $C$ are strongly twisted from one another. The angle between their mean planes is $69.4^{\circ}$.

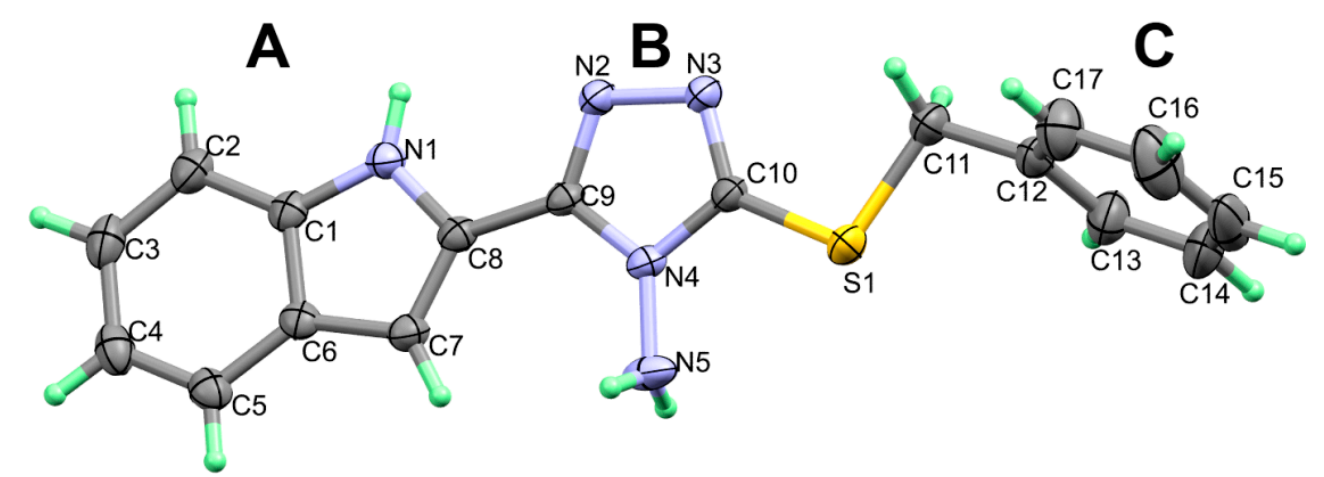

Figure 1. X-ray structure showing atom numbering and thermal ellipsoids at $30 \%$ probability level. 
Table 1. Crystal and refinements data of 2 .

\begin{tabular}{cc}
\hline CCDC & $\mathbf{2 0 1 5 1 7 0}$ \\
\hline empirical formula & $\mathrm{C}_{17} \mathrm{H}_{15} \mathrm{~N}_{5} \mathrm{~S}$ \\
fw & 321.41 \\
temp $(\mathrm{K})$ & 293 \\
$\lambda(\AA)$ & 1.54178 \\
cryst syst & Monoclinic, \\
space group & $\mathrm{C} 2 / \mathrm{c}$ \\
$a(\AA)$ & $35.5589(12)$ \\
$b(\AA)$ & $8.1219(3)$ \\
$c(\AA)$ & $10.9230(4)$ \\
$\beta(\mathrm{deg})$ & $105.081(3)$ \\
$V\left(\AA^{3}\right)$ & $3045.98(19)$ \\
$\mathrm{Z}$ & 8 \\
$\rho_{\text {calc }}\left(\mathrm{Mg} / \mathrm{m}^{3}\right)$ & 1.402 \\
$\mu(\mathrm{Mo} \mathrm{K} \alpha)\left(\mathrm{mm}^{-1}\right)$ & 1.94 \\
No. reflns. & 42061 \\
$\mathrm{Uniqu}_{\mathrm{iqu}}$ reflns. & 2794 \\
$\mathrm{GOOF}\left(\mathrm{F}^{2}\right)$ & 1.05 \\
$\mathrm{R}_{\text {int }}$ & 0.052 \\
$R_{1}{ }^{\mathrm{a}}(I \geq 2 \sigma)$ & 0.043 \\
$\mathrm{w}_{2}{ }^{\mathrm{b}}(I \geq 2 \sigma)$ & 0.114 \\
\hline
\end{tabular}

The molecular packing of 2 is controlled mainly by strong N-H...N hydrogen bonds listed in Table 2 and shown in Figure 2A. In addition, there is one N-H... $\pi$ interaction between one N-H bond of the amino group and carbon atom from phenyl ring in a neighboring molecule with $\mathrm{H}$...C distance of $2.389 \AA$. The packing of molecular units via strong $\mathrm{N}-\mathrm{H} . . . \mathrm{N}$ and weak $\mathrm{N}-\mathrm{H} . . . \pi$ interactions is shown in Figure 2B.

Table 2. Hydrogen-bond geometry ( $)$.

\begin{tabular}{ccccc}
\hline $\boldsymbol{D}-\mathbf{H} \cdots \boldsymbol{A}$ & $\mathbf{D}-\mathbf{H}$ & $\mathbf{H} \cdots \boldsymbol{A}$ & $\boldsymbol{D} \cdots \boldsymbol{A}$ & $\boldsymbol{D}-\mathbf{H} \cdots \boldsymbol{A}$ \\
\hline $\mathrm{N} 5-\mathrm{H} 2 B B \cdots \mathrm{N} 3^{\mathrm{i}}$ & $0.83(3)$ & $2.29(3)$ & $3.104(3)$ & $167(3)$ \\
$\mathrm{N} 1-\mathrm{H} 1 A \cdots \mathrm{N} 2^{\mathrm{ii}}$ & $0.86(2)$ & $2.14(2)$ & $2.947(2)$ & $158(2)$ \\
\multicolumn{4}{c}{ Symmetry codes: (i) $x,-y+1, z-1 / 2 ;(\mathrm{ii})-x+1, y,-z+3 / 2}$. \\
\hline
\end{tabular}
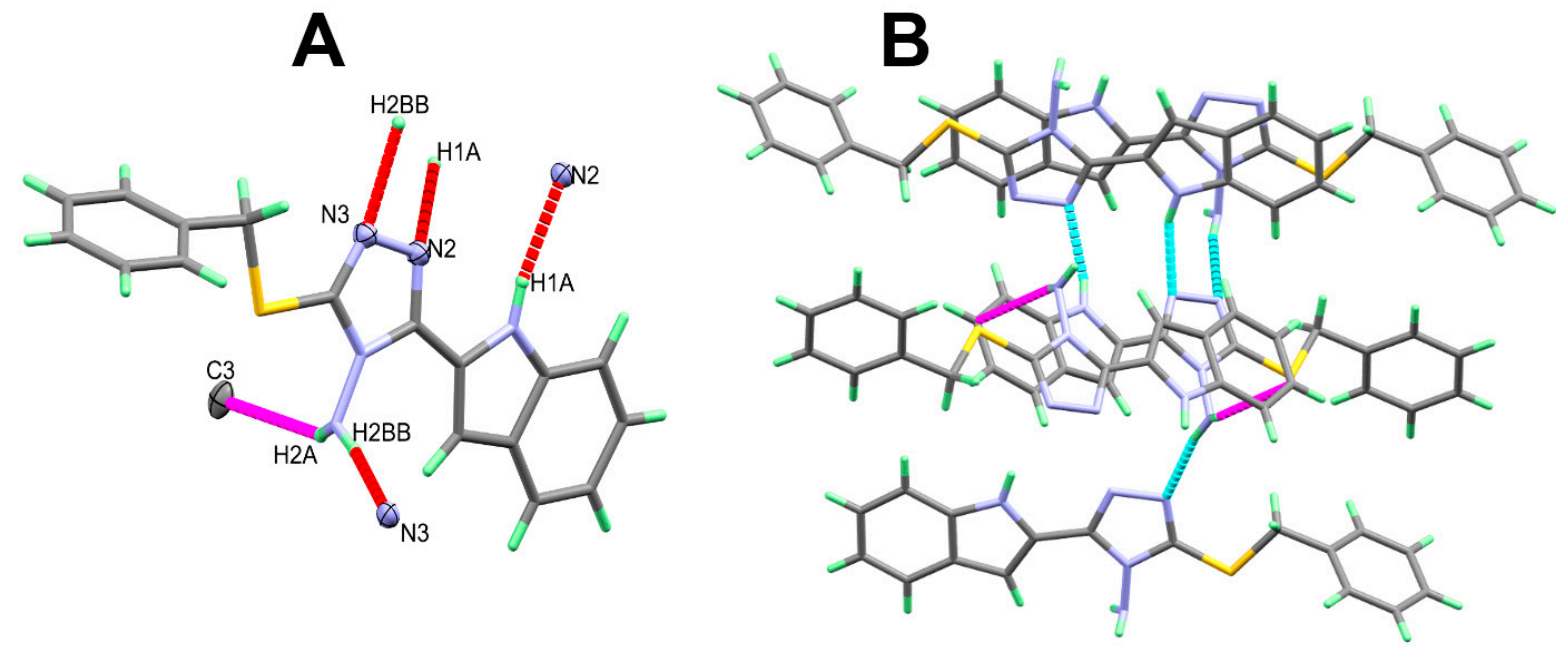

Figure 2. Intermolecular contacts (A) and packing (B) of molecular units in 2. For clarity, the N-H... $\pi$ interactions are labelled in magenta dotted lines. 


\subsection{Hirshfeld Analysis of Molecular Packing}

Hirshfeld topology calculations are important to analyze the different intermolecular contacts in the structure of crystalline materials. Additionally, it sheds the light on the significance, strength and percentage of each intermolecular contact. The percentages of different contacts observed in the crystal structure of 2 based on Hirshfeld calculations are shown in Figure 3, while the complete Hirshfeld surfaces are given in Figure S7 (Supplementary Data). The packing of molecules in the crystal is mainly dependant on significant N...H (1.994-2.595 ̊́) and S... H (2.282 ̊́) contacts, as well as weak C...H contact with minimum C...H distance of 2.670 Á corresponding to the N-H... $\pi$ interaction. Presentation of the N...H and S... H hydrogen bonds and the weak C...H interactions mapped over

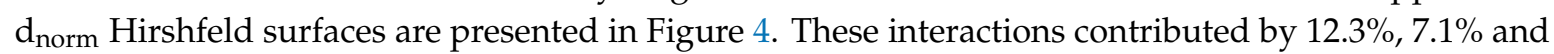
$21.1 \%$ from the whole fingerprint area, respectively. Only the N...H, C...H and S...H contacts appeared as red spots in the corresponding $\mathrm{d}_{\text {norm }}$ maps, indicating their significance (Figure 4 ). The contributions of the weaker H...H, C...N and C...C interactions are $48.4 \%, 4.6 \%$ and $6.1 \%$, respectively. These contacts appeared either as white or blue regions, indicating less important interactions.

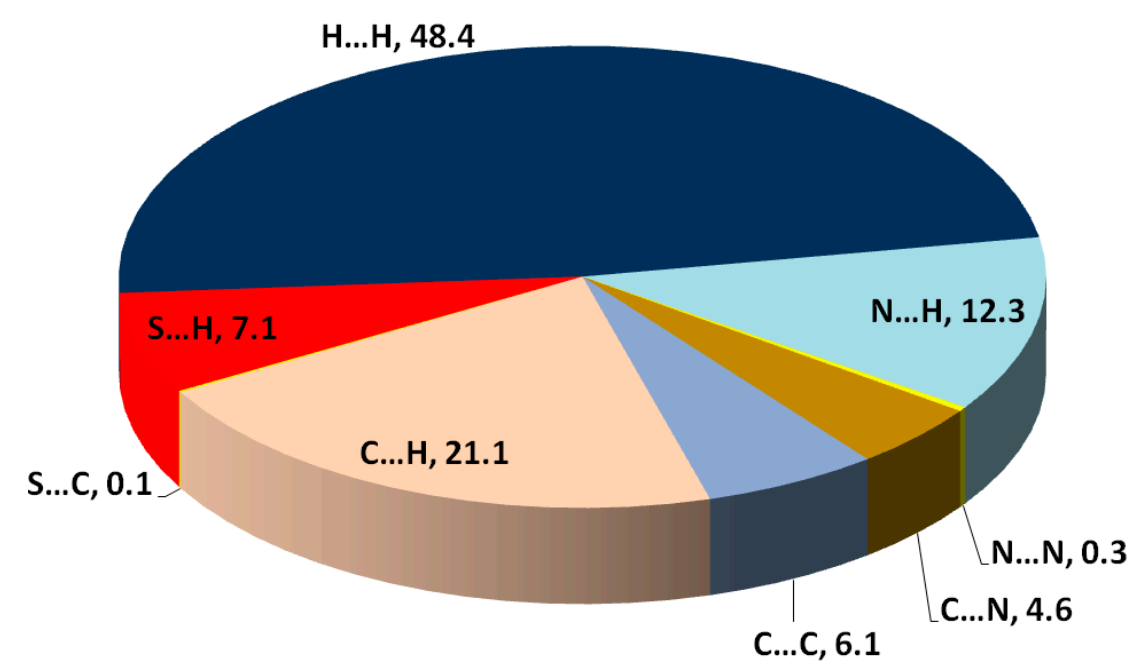

Figure 3. Summary of the intermolecular interactions contributed in the molecular packing of 2 and their percentages.

The presence of some C...C (6.1\%) and C...N (4.6\%) contacts, as well as the blue/red triangles in the shape index Hirshfeld surface (Figure 5), are the main characteristics for the presence of $\pi-\pi$ stacking interactions. The shortest C...C and C...N interaction distances are presented in Table 3. Generally, all these contacts are slightly longer than the van der Waals radii sum of the interacting elements, indicating weak $\pi-\pi$ contacts.

Table 3. Contact distances of the most significant $\pi-\pi$ interactions.

\begin{tabular}{|c|c|}
\hline Contact & Distance (Å) \\
\hline C2...C10 & 3.482 \\
\hline C9...N1 & 3.309 \\
\hline C6...C7 & 3.500 \\
\hline С9...C5 & 3.447 \\
\hline
\end{tabular}


(a)
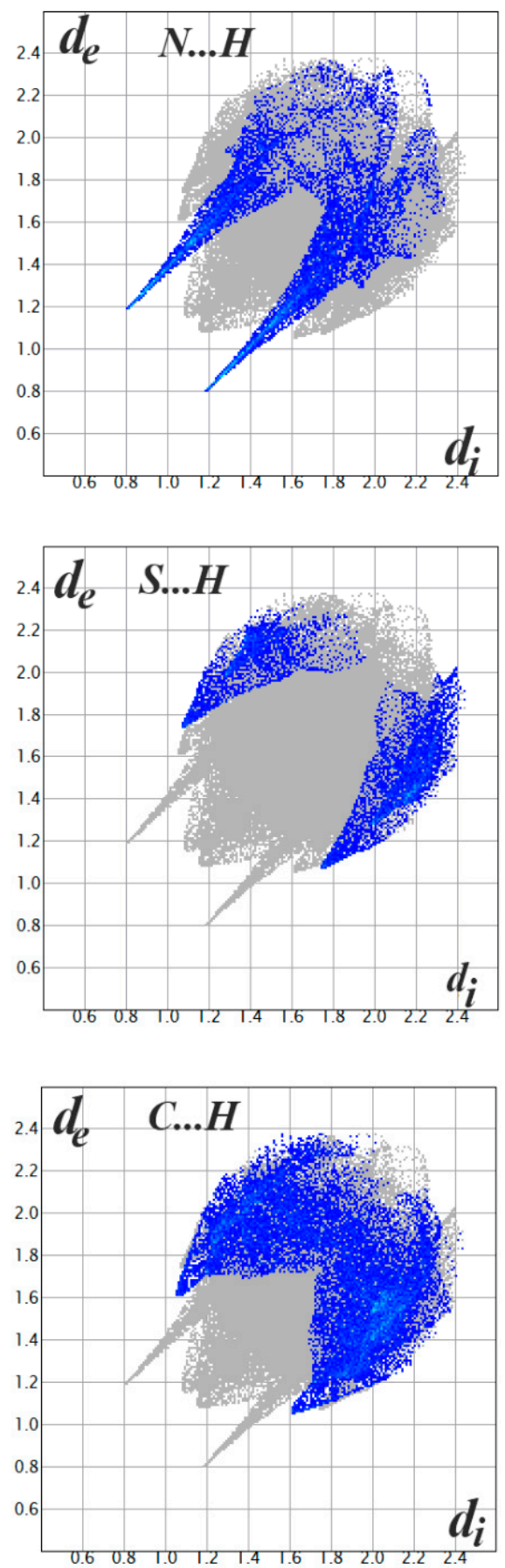

(b)
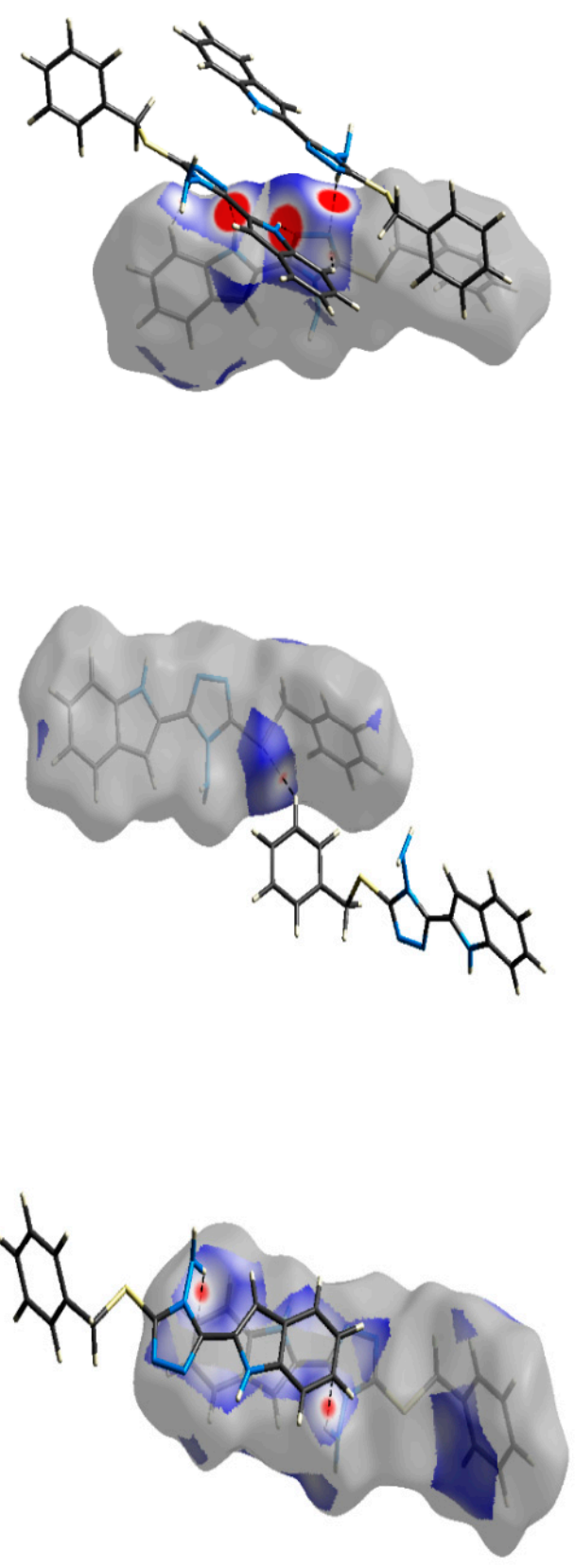

Figure 4. Fingerprint plot $(\mathbf{a})$ and $d_{\text {norm }}$ surfaces $(\mathbf{b})$ of the N...H, S...H and C...H contacts.

DFT studies: the optimized geometry of $\mathbf{2}$ is presented in Figure 6. Structure matching between the computed molecular geometry with the experimental one is also presented. This structure comparison indicated very well the good agreement between the optimized and X-ray structures. In addition, the very good straight-line relations between the calculated and experimental geometric parameters further confirm this conclusion. The values of correlation coefficients are very close to 1 for both cases (Figure 7). A complete set of bond distances and angles are given in Table S3 (Supplementary Data). 


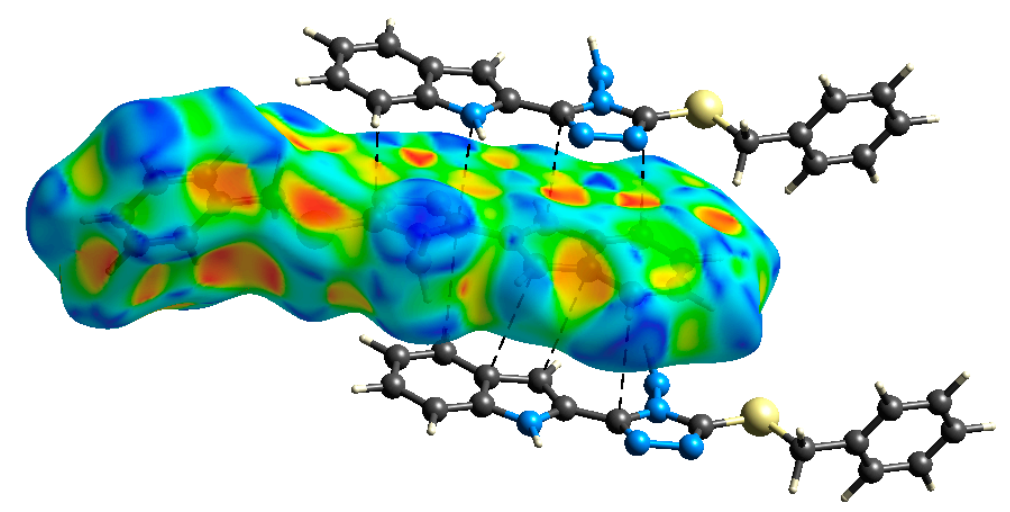

Figure 5. Shape index map showing the shortest $\pi-\pi$ interactions.

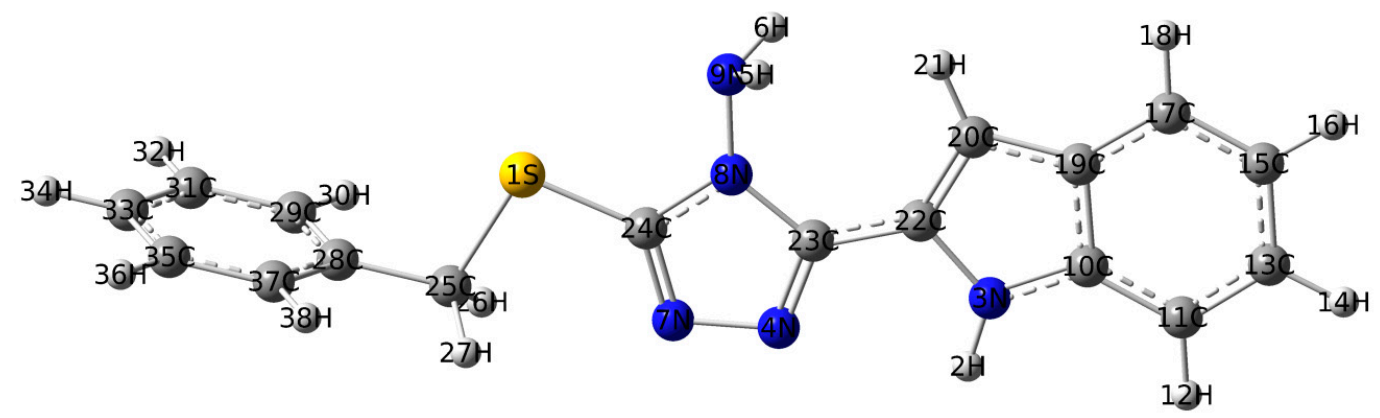

(a)

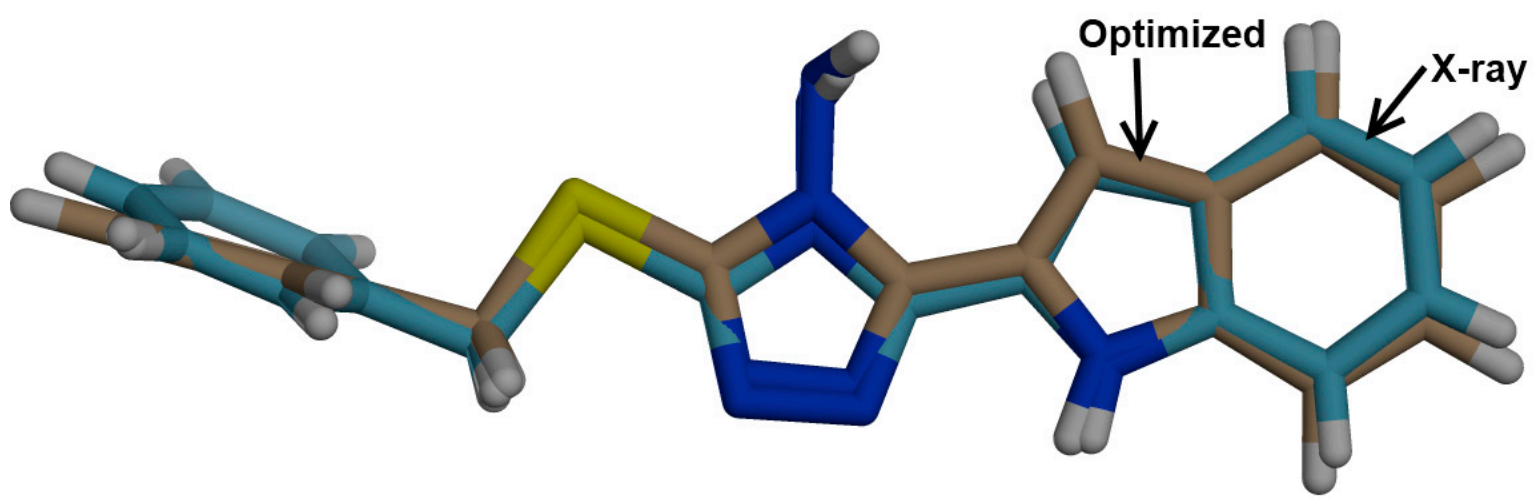

(b)

Figure 6. The optimized geometry (a) and overlay of the optimized (beige) with experimental (blue) structures, (b) for 2 .

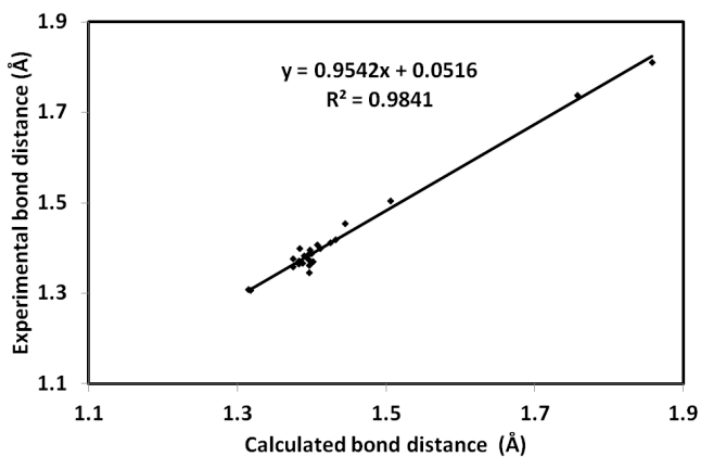

(a)

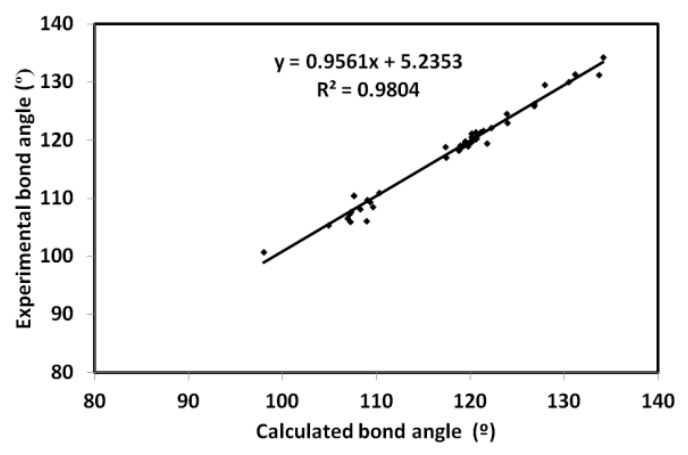

(b)

Figure 7. The straight-line correlations between the calculated and experimental bond distances (a) and angles (b). 
The natural charges obtained from the NBO calculations are listed in Table 4. All hydrogen atoms are electropositive with the highest partial charges located at the $\mathrm{NH}$ protons. Additionally, the sulphur atom has partial positive charge of $0.3054 \mathrm{e}$. In contrast, all nitrogen atoms have negative partial charges. The maximum negative charge is located over the amine nitrogen atom. Additionally, all carbon atoms have negative partial charges except those attached directly to the electronegative nitrogen sites. As a result of this charge distribution, the compound is predicted to be polar molecule with calculated dipole moment of 2.2557 Debye. Molecular electrostatic potential (MESP), along with the dipole vector are presented Figure 8.

Table 4. Natural atomic charges of $2^{\mathrm{a}}$.

\begin{tabular}{cccccc}
\hline Atom & Charge & Atom & Charge & Atom & Charge \\
\hline S1 & 0.3054 & H14 & 0.2407 & H27 & 0.2710 \\
\hline H2 & 0.4576 & C15 & -0.2591 & C28 & -0.0665 \\
\hline N3 & -0.5417 & H16 & 0.2398 & C29 & -0.2214 \\
\hline N4 & -0.3081 & C17 & -0.2186 & H30 & 0.2416 \\
\hline H5 & 0.4021 & H18 & 0.2383 & C31 & -0.2323 \\
\hline H6 & 0.4021 & C19 & -0.0967 & H32 & 0.2418 \\
\hline N7 & -0.3403 & C20 & -0.2941 & C33 & -0.2344 \\
\hline N8 & -0.2463 & H21 & 0.2344 & H34 & 0.2409 \\
\hline N9 & -0.6977 & C22 & 0.1107 & C35 & -0.2323 \\
\hline C10 & 0.1683 & C23 & 0.3179 & H36 & 0.2418 \\
\hline C11 & -0.2683 & C24 & 0.1917 & C37 & -0.2214 \\
\hline H12 & 0.2423 & C25 & -0.5854 & H38 & 0.2416 \\
\hline C13 & -0.2361 & H26 & 0.2710 & & \\
\hline
\end{tabular}

${ }^{\mathrm{a}}$ Atom numbering refer to Figure 6.

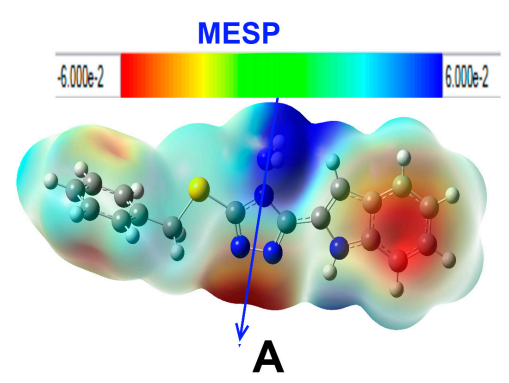

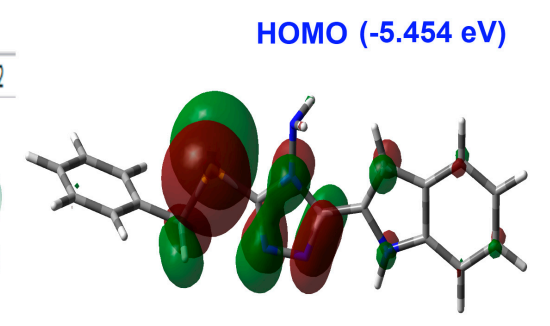

B

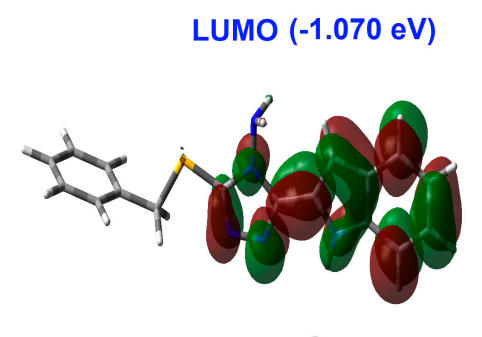

C

Figure 8. The molecular electrostatic potential (MESP; (A)), highest occupied (HOMO; (B)) and lowest unoccupied molecular orbitals (LUMO; (C)) of 2.

In addition, the HOMO and LUMO are important for the molecule reactivity [33-39]. Their energies were calculated to be -5.454 and $-1.070 \mathrm{eV}$, respectively. The energies of these molecular orbitals were used to calculate the reactivity descriptors using Equations (1)-(5).

$$
\begin{gathered}
\mathrm{I}=-\mathrm{E}_{\mathrm{HOMO}} \\
\mathrm{A}=-\mathrm{E}_{\mathrm{LUMO}} \\
\eta=(\mathrm{I}-\mathrm{A}) / 2 \\
\mu=-(\mathrm{I}+\mathrm{A}) / 2 \\
\omega=\mu^{2} / 2 \eta
\end{gathered}
$$


Hence, the calculated ionization potential (I) and electron affinity (A) are 5.454 and $1.070 \mathrm{eV}$, respectively. Additionally, the hardness $(\eta)$, electrophilicity index $(\omega)$ and chemical potential $(\mu)$ are $4.384,1.213$ and $-3.262 \mathrm{eV}$, respectively.

The HOMO is located over the sulphur atom and the triazole $\pi$-system. These sites represent the ground state demand for electronic transition to the higher energy level (LUMO). The latter is distributed over the triazole and indole moieties. Hence, the HOMO to LUMO excitation represent mixed $n-\pi^{*}$ and $\pi-\pi^{*}$ transitions. The energy needed for this intermolecular charge transfer is $4.384 \mathrm{eV}$.

UV-Vis and NMR spectra: The experimental UV-Vis electronic spectra of 2 in ethanol showed absorption bands at 244 and $307 \mathrm{~nm}$, and a shoulder at $295 \mathrm{~nm}$. The assignments of these electronic transitions are presented in Table 5 based on the TD-DFT calculations. The experimental and simulated electronic spectra are shown in Figure 9. The experimentally observed bands were calculated at $232.3 \mathrm{~nm}(\mathrm{f}=0.248), 305.5 \mathrm{~nm}(\mathrm{f}=1.020)$ and $288.8 \mathrm{~nm}(\mathrm{f}=0.069)$, respectively, which correspond to $\mathrm{HOMO} \rightarrow \mathrm{L}+3(81 \%), \mathrm{HOMO} \rightarrow \mathrm{LUMO}(96 \%)$ and $\mathrm{H}-1 \rightarrow$ LUMO $(92 \%)$ transitions, respectively. Presentation of the molecular orbitals involved in these electronic transitions is shown in Figure 10.

Table 5. Assignment of the electronic spectra of 2.

\begin{tabular}{ccccc}
\hline No. & $\left(\boldsymbol{\lambda}_{\text {max }}\right)_{\text {calc }}$ & $\mathbf{f}_{\text {osc }}{ }^{\mathbf{a}}$ & Assignment & $\left(\boldsymbol{\lambda}_{\text {max }}\right)_{\text {obs. }}$ \\
\hline I & 305.5 & 1.020 & HOMO $\rightarrow$ LUMO $(96 \%)$ & 307 \\
II & 288.8 & 0.069 & H-1 $\rightarrow$ LUMO $(92 \%)$ & 295 \\
III & 232.3 & 0.248 & HOMO $\rightarrow$ L $+3(81 \%)$ & 244 \\
\hline \multicolumn{5}{c}{ a oscillator strength. }
\end{tabular}

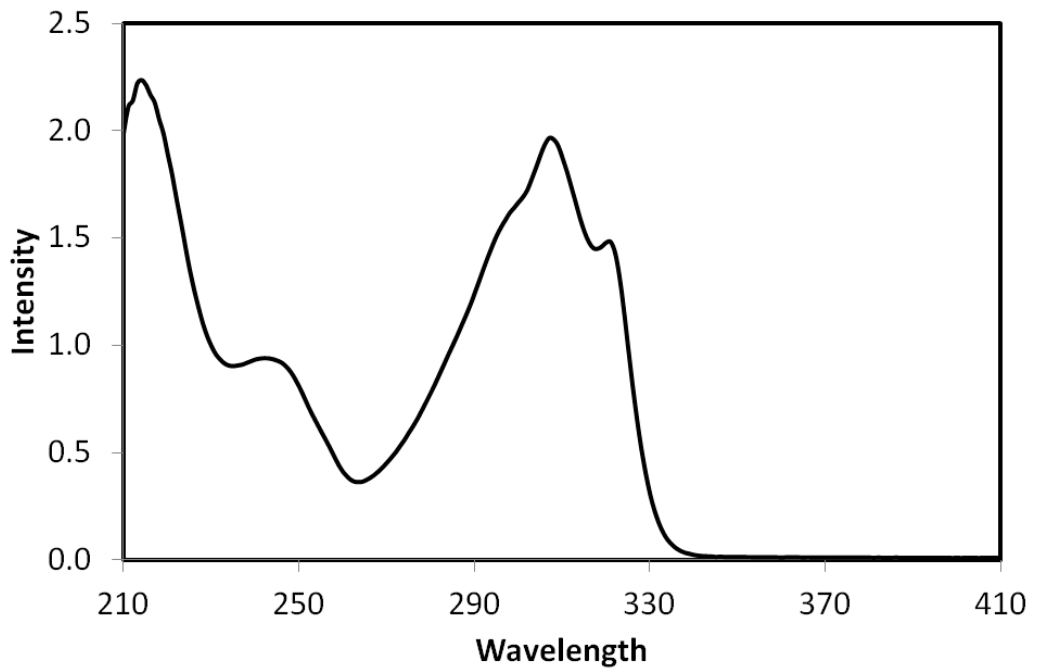

(a)

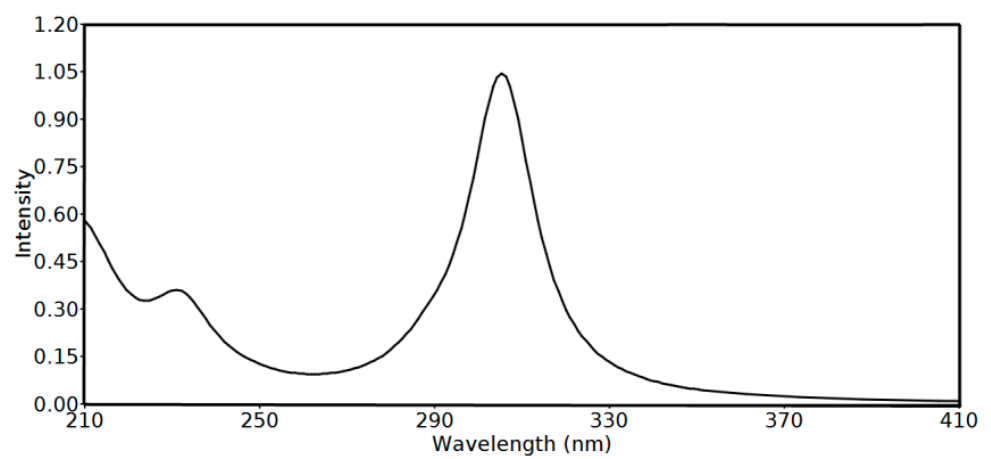

(b)

Figure 9. The experimental (a) and simulated (b) Uv-Vis spectra of 2 using the time-dependant density functional theory (TD-DFT) method. 

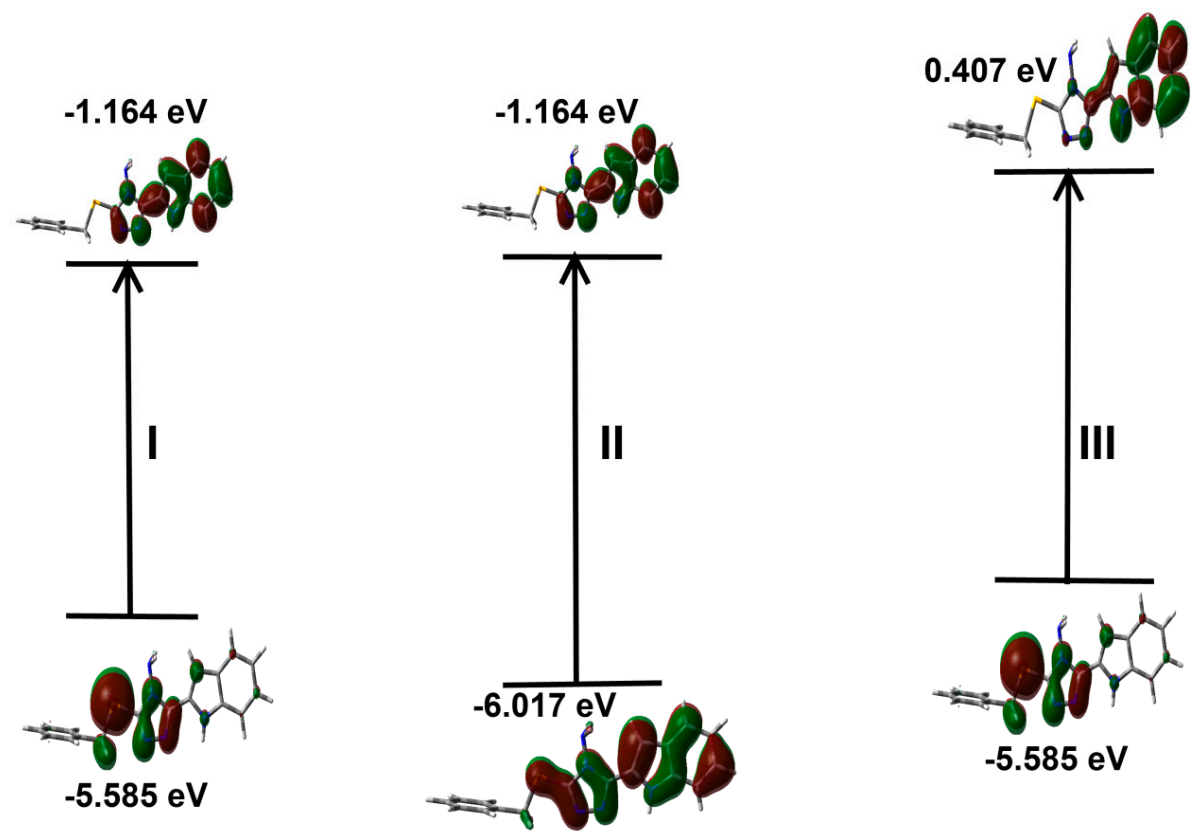

Figure 10. Presentation of the molecular orbitals included in the electronic transitions of 2 in ethanol as solvent. The definition of I, II and III refer to Table 5.

In addition, the geometry optimization is performed in DMSO as solvent, then the NMR chemical shifts are calculated in the same solvent using TMS as internal standard. The results are summarized in Table S4 (Supplementary Data), in comparison with the experimental data. Moreover, graphical plots of the experimental chemical shifts against the calculated data for protons and carbons are presented in Figure 11. As can be seen from this figure, the straight lines have good correlation coefficients, indicating the good agreement between the calculated and experimental results.

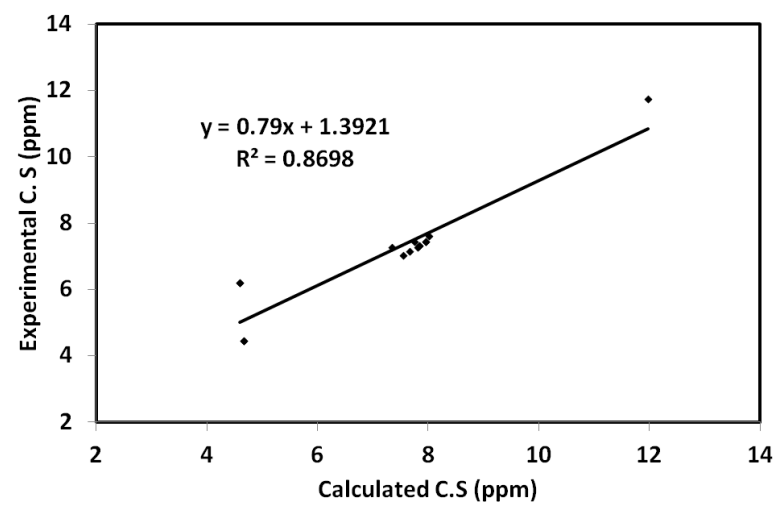

(a)

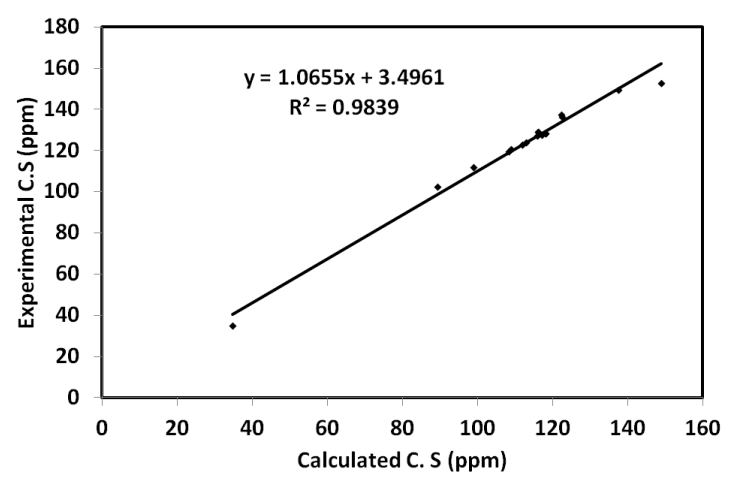

(b)

Figure 11. Correlation graphs between the calculated and experimental ${ }^{1} \mathrm{H}(\mathbf{a})$ and ${ }^{13} \mathrm{C}(\mathbf{b}) \mathrm{NMR}$ chemical shifts.

NBO analysis: the electron delocalization processes from occupied orbitals to antibonding empty orbitals stabilized the system, due to the conjugation effect $[40,41]$. The stabilization energies $\left(\mathrm{E}^{(2)}\right)$ of these electron delocalization processes in 2 are listed in Table 6. The molecule is stabilized by many $\sigma-\sigma^{*}, \pi \rightarrow \pi^{*}, \mathrm{n} \rightarrow \sigma^{*}$ and $\mathrm{n} \rightarrow \pi^{*}$ IMCT interactions. The $\sigma-\sigma^{*}$ and $\mathrm{n} \rightarrow \sigma^{*}$ IMCT interactions are generally weak, with maximum stabilization of 6.79 and $9.95 \mathrm{kcal} / \mathrm{mol}$ for $\sigma(\mathrm{C} 19-\mathrm{C} 20) \rightarrow \sigma^{*} \mathrm{C} 22-\mathrm{C} 23$ and $\mathrm{n}(\mathrm{N} 9) \rightarrow \sigma^{*}$ (N8-C23) IMCT interactions, respectively. In contrast, the $\pi \rightarrow \pi^{*}$, and $\mathrm{n} \rightarrow \pi^{*}$ are generally stronger, which stabilized the system up to 20.67 and $45.73 \mathrm{kcal} / \mathrm{mol}$ for $\pi(\mathrm{C} 31-\mathrm{C} 33) \rightarrow \pi^{*}(\mathrm{C} 28-\mathrm{C} 29)$ and $\mathrm{n}(\mathrm{N} 8) \rightarrow \pi^{*}(\mathrm{~N} 7-\mathrm{C} 24)$ IMCT interactions, respectively. 
Table 6. The $\mathrm{E}^{(2)}(\mathrm{kcal} / \mathrm{mol})$ values for the intramolecular charge transfer interactions in $\mathbf{2}^{\mathrm{a}}$.

\begin{tabular}{cccccc}
\hline Donor NBO & Acceptor NBO & $\mathbf{E}^{(\mathbf{2})}$ & Donor NBO & Acceptor NBO & $\mathbf{E}^{(\mathbf{2})}$ \\
\hline $\boldsymbol{\sigma} \rightarrow \boldsymbol{\sigma}^{*}$ & & & $\mathbf{n} \rightarrow \boldsymbol{\sigma}^{*}$ & & \\
$\sigma(\mathrm{N} 4-\mathrm{N} 7)$ & $\sigma^{*} \mathrm{C} 22-\mathrm{C} 23$ & 5.88 & $\mathrm{n}(\mathrm{S} 1)$ & $\sigma^{*}(\mathrm{~N} 7-\mathrm{C} 24)$ & 5.14 \\
$\sigma(\mathrm{C} 11-\mathrm{C} 13)$ & $\sigma^{*} \mathrm{~N} 3-\mathrm{C} 10$ & 6.19 & $\mathrm{n}(\mathrm{N} 4)$ & $\sigma^{*}(\mathrm{~N} 8-\mathrm{C} 23)$ & 8.53 \\
$\sigma(\mathrm{C} 19-\mathrm{C} 20)$ & $\sigma^{*} \mathrm{C} 22-\mathrm{C} 23$ & 6.79 & $\mathrm{n}(\mathrm{N} 7)$ & $\sigma^{*}(\mathrm{~N} 4-\mathrm{C} 23)$ & 5.34 \\
$\sigma(\mathrm{C} 20-\mathrm{C} 22)$ & $\sigma^{*} \mathrm{C} 17-\mathrm{C} 19$ & 5.10 & $\mathrm{n}(\mathrm{N} 7)$ & $\sigma^{*}(\mathrm{~N} 8-\mathrm{C} 24)$ & 7.96 \\
& & & $\mathrm{n}(\mathrm{N} 9)$ & $\sigma^{*}(\mathrm{~N} 8-\mathrm{C} 23)$ & 9.95 \\
$\pi(\overline{\mathrm{n}} \boldsymbol{\pi}$ & & & $\mathbf{n} \rightarrow \pi^{*}$ & & \\
$\pi(\mathrm{N} 4-\mathrm{C} 23)$ & $\pi^{*}(\mathrm{~N} 7-\mathrm{C} 24)$ & 12.86 & $\mathrm{n}(\mathrm{S} 1)$ & $\pi^{*}(\mathrm{~N} 7-\mathrm{C} 24)$ & 26.92 \\
$\pi(\mathrm{N} 7-\mathrm{C} 24)$ & $\pi^{*}(\mathrm{C} 20-\mathrm{C} 22)$ & 11.51 & $\mathrm{n}(\mathrm{N} 3)$ & $\pi^{*}(\mathrm{C} 10-\mathrm{C} 19)$ & 37.53 \\
$\pi(\mathrm{C} 10-\mathrm{C} 19)$ & $\pi^{*}(\mathrm{~N} 4-\mathrm{C} 23)$ & 13.01 & $\mathrm{n}(\mathrm{N} 3)$ & $\pi^{*}(\mathrm{C} 20-\mathrm{C} 22)$ & 40.71 \\
$\pi(\mathrm{C} 10-\mathrm{C} 19)$ & $\pi^{*}(\mathrm{C} 11-\mathrm{C} 13)$ & 17.86 & $\mathrm{n}(\mathrm{N} 8)$ & $\pi^{*}(\mathrm{~N} 4-\mathrm{C} 23)$ & 44.71 \\
$\pi(\mathrm{C} 10-\mathrm{C} 19)$ & $\pi^{*}(\mathrm{C} 20-\mathrm{C} 22)$ & 19.05 & $\mathrm{n}(\mathrm{N} 8)$ & $\pi^{*}(\mathrm{~N} 7-\mathrm{C} 24)$ & 45.73 \\
$\pi(\mathrm{C} 11-\mathrm{C} 13)$ & $\pi^{*}(\mathrm{C} 10-\mathrm{C} 19)$ & 19.87 & & & \\
$\pi(\mathrm{C} 11-\mathrm{C} 13)$ & $\pi^{*}(\mathrm{C} 15-\mathrm{C} 17)$ & 17.07 & & & \\
$\pi(\mathrm{C} 15-\mathrm{C} 17)$ & $\pi^{*}(\mathrm{C} 10-\mathrm{C} 19)$ & 16.68 & & & \\
$\pi(\mathrm{C} 15-\mathrm{C} 17)$ & $\pi^{*}(\mathrm{C} 11-\mathrm{C} 13)$ & 19.33 & & & \\
$\pi(\mathrm{C} 20-\mathrm{C} 22)$ & $\pi^{*}(\mathrm{~N} 4-\mathrm{C} 23)$ & 17.99 & & & \\
$\pi(\mathrm{C} 20-\mathrm{C} 22)$ & $\pi^{*}(\mathrm{C} 10-\mathrm{C} 19)$ & 15.84 & & & \\
$\pi(\mathrm{C} 31-\mathrm{C} 33)$ & $\pi^{*}(\mathrm{C} 28-\mathrm{C} 29)$ & 20.67 & & & \\
$\pi(\mathrm{C} 31-\mathrm{C} 33)$ & $\pi^{*}(\mathrm{C} 35-\mathrm{C} 37)$ & 20.18 & & & \\
$\pi(\mathrm{C} 35-\mathrm{C} 37)$ & $\pi^{*}(\mathrm{C} 28-\mathrm{C} 29)$ & 20.53 & & & \\
$\pi(\mathrm{C} 35-\mathrm{C} 37)$ & $\pi^{*}(\mathrm{C} 31-\mathrm{C} 33)$ & 20.29 & & & \\
\hline
\end{tabular}

${ }^{a}$ Atom numbering refer to Figure 6.

\section{Conclusions}

S-Benzylation of 4-amino-5-(1H-indol-2-yl)-1,2,4-triazol-3(2H)-thione was done with benzyl bromide and stirring overnight in the presence of $\mathrm{K}_{2} \mathrm{CO}_{3}$ as an acid scavenger in ethanol, which afforded 3-(benzylsulfanyl)-5-(1H-indol-2-yl)-4H-1,2,4-triazol-4-amine in excellent yield. The different interactions affecting the molecular packing in the crystal of 2 were determined using Hirshfeld calculations. The N...H, S... H, C...H and $\pi-\pi$ interactions are the most important based on the Hirshfeld analysis. Using TD-DFT calculations, the two Uv-Vis spectral bands at 244 and $307 \mathrm{~nm}$ and the shoulder at $295 \mathrm{~nm}$ were assigned to be for $\mathrm{HOMO} \rightarrow \mathrm{L}+3(81 \%), \mathrm{HOMO} \rightarrow \mathrm{LUMO}(96 \%)$ and $\mathrm{H}-1 \rightarrow \mathrm{LUMO}$ $(92 \%)$ transitions, respectively. Additionally, NMR spectra of the compound were matched with the calculated gauge-including atomic orbitals (GIAO) chemical shifts.

Supplementary Materials: The following are available online at http://www.mdpi.com/2073-4352/10/8/685/s1. Figure S1: ${ }^{1} \mathrm{H}$ NMR of the target compound; Figure S2: ${ }^{13} \mathrm{C}$ NMR of the target compound; Figure S3: D-COSY of the target compound; Figure S4: DEPT-135 of the target compound; Figure S5: DEPT-90 of the target compound; Figure S6: 2D-HMQC of the target compound; Figure S7: LRMS (EI) of the target compound; Figure S8: Hirshfeld surfaces of 2; Table S1: Bond lengths for 2; Table S2: Bond angles for 2; Table S3: The calculated geometric parameters of the studied compound ${ }^{a}$; Table S4: The calculated and experimental chemical shifts (ppm) for the studied compound ${ }^{\mathrm{a}}$.

Author Contributions: Conceptualization, A.T.A.B. and A.B.; Data curation, S.M.S. and S.Y.; Formal analysis, S.Y.; Investigation, A.T.A.B.; Methodology, A.T.A.B.; Software, S.M.S.; Visualization, S.M.S. and A.B.; funding acquisition: A.B. Writing-original draft, A.T.A.B., S.M.S. and A.B. All authors approved the final version. All authors have read and agreed to the published version of the manuscript.

Funding: The research project funded by King Saud University, Researchers Supporting Project Number (RSP-2020/64).

Acknowledgments: The authors would like to extend their sincere appreciation to Researchers Supporting Project Number (RSP-2020/64), King Saud University, Riyadh, Saudi Arabia.

Conflicts of Interest: The authors declare no conflict of interest. 


\section{References}

1. Kaur, R.; Dwivedi, A.R.; Kumar, B.; Kumar, V. Recent developments on 1, 2, 4-triazole nucleus in anticancer compounds: A review. Anti-Cancer Agent. Med. Chem. 2016, 16, 465-489. [CrossRef] [PubMed]

2. Ayati, A.; Emami, S.; Foroumadi, A. The importance of triazole scaffold in the development of anticonvulsant agents. Eur. J. Med. Chem. 2016, 109, 380-392. [CrossRef] [PubMed]

3. Amer, A.; Ayoup, M.S.; Khattab, S.N.; Hassan, S.Y.; Langer, V.; Senior, S.; El Massry, A.M. A regio-and stereo-controlled approach to triazoloquinoxalinyl C-nucleosides. Carbohydr. Res. 2010, 345, 2474-2484. [CrossRef] [PubMed]

4. Keri, R.S.; Patil, S.A.; Budagumpi, S.; Nagaraja, B.M. Triazole: A Promising Antitubercular Agent. Chem. Biol. Drug Des. 2015, 86, 410-423. [CrossRef] [PubMed]

5. Ayoup, M.S.; Ahmed, H.E.A.; El Massry, A.M.; Senior, S.; Khattab, S.N.; Hassan, S.Y.; Amer, A. Synthesis, Docking, and Evaluation of Antimicrob. Activity of a New Series of Acyclo C-Nucleosides of 1,2,4-Triazolo [4, 3-a] quinoxaline Derivatives. J. Heterocycl. Chem. 2016, 53, 153-163. [CrossRef]

6. Khan, I.; Ibrar, A.; Abbas, N. Triazolothiadiazoles and triazolothiadiazines-biologically attractive scaffolds. Eur. J. Med. Chem. 2013, 63, 854-868. [CrossRef]

7. Kucukguzel, S.G.; Cikla-Suzgun, P. Recent advances bioactive 1, 2, 4-triazole-3-thiones. Eur. J. Med. Chem. 2015, 97, 830-870. [CrossRef]

8. Abdelhameed, R.M.; El-Sayed, H.A.; El-Shahat, M.; El-Sayed, A.A.; Darwesh, O.M. Novel triazolothiadiazole and triazolothiadiazine derivatives containing pyridine moiety: Design, synthesis, bactericidal and fungicidal activities. Curr. Bioact. Compd. 2018, 14, 169-179. [CrossRef]

9. Sumangala, V.; Poojary, B.; Chidananda, N.; Arulmoli, T.; Shenoy, S. Synthesis and biological evaluation of some Schiff bases of 4-amino-5-(4-methylsulfonyl) benzyl-2, 4-dihydro-3H-[1,2,4]-triazole-3-thione. Med. Chem. Res. 2013, 22, 2921-2928. [CrossRef]

10. Guo, L.; Wu, M.; Leng, S.; Qiang, Y.; Zheng, X. Synergistic effect of purpald with tartaric acid on the corrosion inhibition of mild steel: From electrochemical to theoretical insights. Prot. Met. Phys. Chem. Surf. 2018, 54, 917-925. [CrossRef]

11. Yan, D.; Xiang, Y.; Li, K.; Chen, Y.; Yang, Z.; Guo, D. Synthesis, characterization and properties of 1, 2, 4-triazolo [3-b][1,3,4] thiadiazole derivatives and their europium complexes. J. Mol. Struct. 2014, 1074, 487-495. [CrossRef]

12. Kochanowska-Karamyan, A.J.; Hamann, M.T. Marine indole alkaloids: Potential new drug leads for the control of depression and anxiety. Chem. Rev. 2010, 110, 4489-4497. [CrossRef] [PubMed]

13. Pingaew, R.; Prachayasittikul, S.; Ruchirawat, S.; Prachayasittikul, V. Synthesis and cytotoxicity of novel 2, 2'-bis-and 2, 2', 2' '-tris-indolylmethanes-based bengacarboline analogs. Arch. Pharm. Res. 2012, 35, 949-954. [CrossRef] [PubMed]

14. Hong, C.; Firestone, G.L.; Bjeldanes, L.F. Bcl-2 family-mediated apoptotic effects of 3, 3'-diindolylmethane (DIM) in human breast cancer cells. Biochem. Pharmacol. 2002, 63, 1085-1097. [CrossRef]

15. Yoo, M.; Choi, S.-U.; Choi, K.Y.; Yon, G.H.; Chae, J.-C.; Kim, D.; Zylstra, G.; Kim, E. Trisindoline synthesis and anticancer activity. Biochem. Biophys. Res. Commun. 2008, 376, 96-99. [CrossRef]

16. Rahman, K.W.; Li, Y.; Wang, Z.; Sarkar, S.H.; Sarkar, F.H. Gene expression profiling revealed survivin as a target of 3, 3'-diindolylmethane-induced cell growth inhibition and apoptosis in breast cancer cells. Cancer Res. 2006, 66, 4952-4960. [CrossRef]

17. Safe, S.; Papineni, S.; Chintharlapalli, S. Cancer chemotherapy with indole-3-carbinol, bis (3'-indolyl) methane and synthetic analogs. Cancer Lett. 2008, 269, 326-338. [CrossRef]

18. Foderaro, T.A.; Barrows, L.R.; Lassota, P.; Ireland, C.M. Bengacarboline, a New $\beta$-Carboline from a Marine Ascidian Didemnum sp. J. Org. Chem. 1997, 62, 6064-6065. [CrossRef]

19. Nagarsenkar, A.; Prajapti, S.K.; Guggilapu, S.D.; Birineni, S.; Kotapalli, S.S.; Ummanni, R.; Babu, B.N. Investigation of triazole-linked indole and oxindole glycoconjugates as potential anticancer agents: Novel Akt/PKB signaling pathway inhibitors. Med. Chem. Commun. 2016, 7, 646-653. [CrossRef]

20. Kaminskyy, D.; Bednarczyk-Cwynar, B.; Vasylenko, O.; Kazakova, O.; Zimenkovsky, B.; Zaprutko, L.; Lesyk, R. Synthesis of new potential anticancer agents based on 4-thiazolidinone and oleanane scaffolds. Med. Chem. Res. 2012, 21, 3568-3580. [CrossRef] 
21. Pingaew, R.; Prachayasittikul, S.; Ruchirawat, S.; Prachayasittikul, V. Synthesis and structure-activity relationship of mono-indole-, bis-indole-, and tris-indole-based sulfonamides as potential anticancer agents. Mol. Divers. 2013, 17, 595-604. [CrossRef] [PubMed]

22. Lai, C.J.; Bao, C.J.; Tao, X.; Wang, J.; Atoyan, R.; Qu, H.; Wang, D.G.; Yin, L.; Samson, M.; Forrester, J.; et al. CUDC-101, a multitargeted inhibitor of histone deacetylase, epidermal growth factor receptor, and human epidermal growth factor receptor 2, exerts potent anticancer activity. Cancer Res. 2010, 70, 3647-3656. [CrossRef] [PubMed]

23. Hamdy, R.; Ziedan, N.; Ali, S.; El-Sadek, M.; Lashin, E.; Brancale, A.; Jones, A.T.; Westwell, A.D. Synthesis and evaluation of 3-(benzylthio)-5-(1H-indol-3-yl)-1,2,4-triazol-4-amines as Bcl-2 inhibitory anticancer agents. Bioorg. Med. Chem. Lett. 2013, 23, 2391-2394. [CrossRef] [PubMed]

24. Boraei, A.T.A.; Gomaa, M.S.; El Sayed, E.S.H.; Duerkop, A. Design, selective alkylation and X-ray crystal structure determination of dihydro-indolyl-1,2,4-triazole-3-thione and its 3-benzylsulfanyl analogue as potent anticancer agents. Eur. J. Med. Chem. 2017, 125, 360-371. [CrossRef]

25. Boraei, A.T.A.; Singh, P.K.; Sechi, M.; Satta, S. Discovery of novel functionalized 1, 2, 4-triazoles as PARP-1 inhibitors in breast cancer: Design, synthesis and antitumor activity evaluation. Eur. J. Med. Chem. 2019, 182, 111621. [CrossRef] [PubMed]

26. Chu, Q.-Z.; Zhou, H.-R.; Zhang, X.-R. 3-benzyl-sulfanyl-5-(4-phenyl-1H-1,2,3-triazol-1-ylmeth-yl)-4H-1,2,4triazol-4-amine. Acta Cryst. 2008, E64, o1611.

27. Boraei, A.T.A.; Sarhan, A.A.M.; Yousuf, S.; Barakat, A. Synthesis of a New Series of Nitrogen/Sulfur Heterocycles by Linking Four Rings: Indole; 1,2,4-Triazole; Pyridazine; and Quinoxaline. Molecules 2020, 25, 450. [CrossRef] [PubMed]

28. Sarhan, A.A.; Boraei, A.T.A.; Barakat, A.; Nafie, M.S. Discovery of hydrazide-based pyridazino [4-b] indole scaffold as a new phosphoinositide 3-kinase (PI3K) inhibitor for breast cancer therapy. RSC Adv. 2020, 10, 19534-19541. [CrossRef]

29. Boraei, A.T.A.; Ghabbour, H.A.; Gomaa, M.S.; El Ashry, E.S.H.; Barakat, A. Synthesis and anti-proliferative assessment of triazolo-thiadiazepine and triazolo-thiadiazine scaffolds. Molecules 2019, 24, 4471. [CrossRef]

30. Badria, F.A.; Soliman, S.M.; Atef, S.; Islam, M.S.; Al-Majid, A.M.; Dege, N.; Ghabbour, H.A.; Ali, M.; El-Senduny, F.F.; Barakat, A. Anticancer Indole-Based Chalcones: A Structural and Theoretical Analysis. Molecules 2019, 24, 3728. [CrossRef]

31. Boraei, A.T.; El Ashry, E.S.H.; Barakat, A.; Ghabbour, H.A. Synthesis of new functionalized indoles based on ethyl indol-2-carboxylate. Molecules 2016, 21, 333. [CrossRef]

32. Boraei, A.T. A new direct synthetic access to 4-Amino-2-N-(glycosyl/propyl)-1,2,4-triazole-3-thiones via hydrazinolysis of 3-N-((Acylated gylcosyl)/allyl)-1,3,4-oxadiazole-2-thiones. Arkivoc 2016, 3, 71-81.

33. Foresman, J.B.; Frisch, A.E. Exploring Chemistry with Electronic Structure Methods, 2nd ed.; Gaussian: Pittsburgh, PA, USA, 1996.

34. Chang, R. Chemistry, 7th ed.; McGraw-Hill: New York, NY, USA, 2001.

35. Kosar, B.; Albayrak, C. Spectroscopic investigations and quantum chemical computational study of (E)-4-methoxy-2-[(p-tolylimino) methyl] phenol. Spectrochim. Acta 2011, 78, 160-167. [CrossRef] [PubMed]

36. Koopmans, T.A. Ordering of wave functions and eigenenergies to the individual electrons of an atom. Physica 1933, 1, 104-113. [CrossRef]

37. Parr, R.G.; Yang, W. Density-Functional Theory of Atoms and Molecules; Oxford University Press: New York, NY, USA, 1989.

38. Parr, R.G.; Szentpaly, L.V.; Liu, S. Electrophilicity index. J. Am. Chem. Soc. 1999, 121, 1922-1924. [CrossRef]

39. Singh, R.N.; Kumar, A.; Tiwari, R.K.; Rawat, P.; Gupta, V.P. A combined experimental and quantum chemical (DFT and AIM) study on molecular structure, spectroscopic properties, NBO and multiple interaction analysis in a novel ethyl 4-[2-(carbamoyl) hydrazinylidene]-3, 5-dimethyl-1H-pyrrole-2-carboxylate and its dimer. J. Mol. Strut. 2013, 1035, 427-440. [CrossRef] 
40. Hubert Joe, I.; Kostova, I.; Ravikumar, C.; Amalanathan, M.; Pinzaru, S.C. Theoretical and vibrational spectral investigation of sodium salt of acenocoumarol. J. Raman Spectrosc. 2009, 40, 1033-1038.

41. Sebastian, S.; Sundaraganesan, N. The spectroscopic (FT-IR, FT-IR gas phase, FT-Raman and UV) and NBO analysis of 4-Hydroxypiperidine by density functional method. Spectrochim. Acta Part A Mol. Biomol. Spectrosc. 2010, 75, 941-952. [CrossRef]

(C) 2020 by the authors. Licensee MDPI, Basel, Switzerland. This article is an open access article distributed under the terms and conditions of the Creative Commons Attribution (CC BY) license (http://creativecommons.org/licenses/by/4.0/). 